\title{
Significance of Cuscutain, a cysteine protease from Cuscuta reflexa, in host-parasite interactions
}

\author{
Marc Bleischwitz ${ }^{1}$, Markus Albert ${ }^{2}$, Hans-Lothar Fuchsbauer ${ }^{3}$, Ralf Kaldenhoff ${ }^{*}$
}

\begin{abstract}
Background: Plant infestation with parasitic weeds like Cuscuta reflexa induces morphological as well as biochemical changes in the host and the parasite. These modifications could be caused by a change in protein or gene activity. Using a comparative macroarray approach Cuscuta genes specifically upregulated at the host attachment site were identified.

Results: One of the infestation specific Cuscuta genes encodes a cysteine protease. The protein and its intrinsic inhibitory peptide were heterologously expressed, purified and biochemically characterized. The haustoria specific enzyme was named cuscutain in accordance with similar proteins from other plants, e.g. papaya. The role of cuscutain and its inhibitor during the host parasite interaction was studied by external application of an inhibitor suspension, which induced a significant reduction of successful infection events.
\end{abstract}

Conclusions: The study provides new information about molecular events during the parasitic plant - host interaction. Inhibition of cuscutain cysteine proteinase could provide means for antagonizing parasitic plants.

\section{Background}

Parasitic weeds such as Cuscuta reflexa are obligate holoparasites with low host specificity. The plants are found in areas with relatively mild climates around the world. In farming regions, these parasites cause substantial damage to many commercially important crops such as sugar beet, alfalfa, pepper, cucumber, tomato potato or allium [1]. Currently, an effective control of Cuscuta outbreaks is based on preventive strategies including control of seed contamination and application of herbicides prior to seed emergence. The use of herbicides on infected plants with an established host parasite interaction only appears to be successful and not harmful to the host plant if the host is herbicide resistant $[2,3]$. Due to difficulties with conventional breeding techniques, molecular biology genomic research on parasites is needed to develop new control strategies [4-8]. Research on host reactions to parasitic plant infection in model plants such as Arabidopsis thaliana, Medicago truncatula and crops like tomato or tobacco have already generated promising results [9-12].

\footnotetext{
* Correspondence: kaldenhoff@bio.tu-darmstadt.de

${ }^{4}$ Darmstadt University of Technology, Applied Plant Science, Schnittspahnstr. 10, 64287 Darmstadt, Germany

Full list of author information is available at the end of the article
}

In Cuscuta spp. photosynthesis is reduced or absent [13]. Consequently, the plant depends on carbohydrates withdrawn from the host plant [14]. A connection (haustorium) at the contact site is established through the secretion of enzymes and sticky substances consisting mainly of de-esterified pectins [15]. At early stages of Cuscuta invasion, host plants react with specific gene expression to regulate processes including calcium release, cell elongation and cell wall modification (Albert, Werner, Proksch, Fry, \& Kaldenhoff 2004; Werner, Uehlein, Proksch, \& Kaldenhoff 2001; [16]. A gene coding for an arabinogalactan protein (AGP) was found to be upregulated in tomato at an early stage of infection and it has a significant function for $C$. reflexa attachment to the host plant (Albert, Belastegui-Macadam, \& Kaldenhoff 2006). After attachment, the host is invaded by hyphae and chimeric cell walls of host and Cuscuta cells are formed [17]. Phloem and xylem connections transfer water, nitrogen-compounds, assimilates and even RNA, proteins or plant viruses from the host to the parasitic plant [18-20].

The current knowledge about gene expression in the parasite Cuscuta at early stages of infection is limited. Besides host responses, parasitic plant reactions need to be determined for a complete elucidation of the 
infection process. This knowledge will likely be one of the prerequisites for the improvement of strategies to prevent or control Cuscuta-infection. For a first overview of parasite responses, we have constructed a Cuscuta cDNA-library corresponding to mRNAs specific for early stages of haustoria development. Here, we describe one of the identified genes, which encodes a Cuscuta reflexa haustoria specific cysteine protease that we named cuscutain. Its expression, biochemical characteristics and significance during the infection process opens the possibility to develop a cuscutain-based strategy against Cuscuta infection.

\section{Results}

\section{Cuscutain}

mRNA from Cuscuta tissue containing haustoria was employed to construct a cDNA library with 7000 primary transformants. Putative haustorium specific expression of the corresponding genes was identified by differential cDNA hybridization (haustorium containing material versus shoot without haustoria) to all obtained cDNA clones assigned on a macroarray. 16 different clones were preselected by this procedure showing a more intense signal on a macroarray chip when hybridized with a cDNA probe from RNA of haustoria containing tissue. One of the signals with a remarkable differential intensity corresponded to a cDNA clone derived from a cysteine proteinase encoding mRNA (Accession No.: FB701665). Because cysteine proteinases were known to participate in some interspecies interactions, we were interested to study the role of this Cuscuta reflexa enzyme. For verification of spatial expression, Cuscuta-RNA from the two tissue types was further characterized by Northern blot with a probe derived from the above said cDNA clone. Just a faint signal was obtained in RNA from Cuscuta shoots lacking haustorial structures and a strong one was obtained in RNA from shoot material with haustoria, which was harvested at three days post attachment (Figure 1). Sequence analysis of the deduced mRNA revealed that translational start and stop codons including poly A tail were cloned as cDNA indicating a full length cDNA-insertion. Sequence comparison obtained from BLAST-n at NCBI revealed a high sequence identity to cysteine proteinases like Ipomoea batatas papain-like cysteine proteinase isoform II (86\%), Phaseolus vulgaris Moldavian encoding cysteine proteinase (78\%) or Arachis hypogaea cysteine protease-like protein (77\%). An equally high identity to numerous cysteine proteinases was observed when the translated sequence was subjected to a comparison with entries from Expasy Proteomics Server at Swiss Institute of Bioinformatics (e.g. 86\% overall identity to Ipomoea batatas papain-like cysteine proteinase isoform II). According to sequence alignment and protein domain identification tools, specific functional

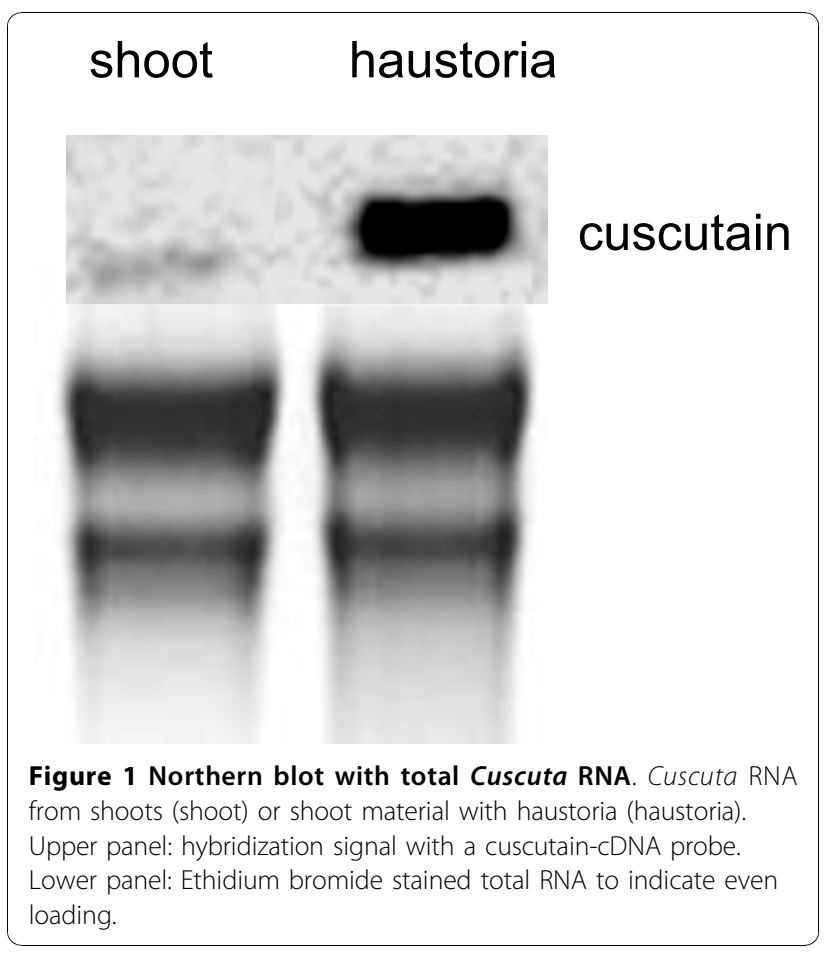

sites could be identified (Figure 2). Hence, the predicted protein consists of a prepeptide, thought to be responsible for its extracellular localization (98.2\% probability). The corresponding cleavage site between prepeptide and the subsequent propeptide is represented by a SSSDD sequence (Figure 2, 99.9\% probability). Next to the prepeptide from $\mathrm{N}$ - to $\mathrm{C}$-terminus the propeptide harbors a so called ERFIN-motif [21], which is a stabilizing component of intramolecular interaction. This protein region was described to form an inhibitor of the proteinase activity [22]. Furthermore the propeptide acts as an intramolecular chaperone [23]. The actual cysteine proteinase region contains characteristic active sites as indicated by motiv search (Prosite, Swiss Institute of Bioinformatics) and comprises a protein with a calculated molecular weight of $24.8 \mathrm{kDa}$. That of the prepeptide is $11.7 \mathrm{kDa}$.

\section{Biochemical characterization of cuscutain and the inhibitory propeptide}

The coding sequence for the propeptide inhibitor region and that for the enzymatic activity were separately cloned into an $E$. coli expression vector. After induction, both proteins were expressed in $E$. coli and could be identified in crude extracts of soluble proteins by SDS gel electrophoresis and Coomassie staining. Nickelcolumn-chromatography was employed to purify the $\mathrm{C}$-terminal $6 \mathrm{xHis}$ tagged proteins and provided a protein solution without significant impurities in the case of the propeptide as demonstrated by SDS gel electrophoresis and Coomassie staining (Figure 3). For the 


\section{MALRISIMFLICSFLIVTTSLGIADGSSSDDILIRQVV GDDGALLSDDHQFTVFKKRFGKAYASEEEHDYRFSVEKK VNMRLAKQHQQLDPSAVRGVTRFSDLTPSEFKRNFLGL NRRLRFPADAQTAPTLPTDDLPSDFDWRDHGAVTAVKN QGSCGSCWSFSTTGALEGANFLATGKLVSLSEQQLVDC DHECDPEEAGSCDSGCNGGLMTSAFEYTLKAGGLMREE DYPYTGNDAQVCNEDKTKIAAKVANESVVSLDEDQIAA NLVKNGPLAVAINAVFMQTYAGGVSCPYICSKRLDHGV LLVGYGSAGYAPVRAKEKPYWVIKNSWGEQWGEKGYYK ICRGSNVCGVDSMVSTVAAVSTNSE}

Figure 2 Predicted cuscutain sequence. Prepeptide (green), propeptide (red) and the catalytic protein (blue) are depicted as well as the cleavage site and the ERFIN-motif (black, underlined).

enzymatic protein portion a further purification step after gel-electrophoresis was applied as outlined. Eventually, also the enzymatic protein part was processed to purity as indicated by the staining of the corresponding gel (Figure 3). The purified enzymatic protein component was subjected to enzymatic characterization and the putative inhibitor component was tested for inhibitor efficiency. The results are summarized in Figure 4 and revealed for the Cuscuta cysteine proteinase $\mathrm{a} \mathrm{K}_{\mathrm{m}}=$ $0,393 \pm 0,02 \mathrm{mM}$ or a turnover number of 3.5 aniline bonds/s (Figure 4A), an optimum at $\mathrm{pH}$ 7.0- 7.5 (Figure $4 \mathrm{~B}$ ) and a temperature optimum at $40^{\circ} \mathrm{C}$ (Figure $4 \mathrm{C}$ ). These figures are in a comparable range to other cysteine proteinases (Table 1). In accordance to the naming of the papaya cysteine proteinase papain, the Cuscuta enzyme was denominated cuscutain. For the predicted inhibitory propeptide a $K_{\mathrm{i}}$ of $0.7 \pm 0.02 \mathrm{nM}$ was determined on cuscutain activity (Fig 4D). The inhibitory effect on other cysteine proteinases like papain or cruzipain was found to be 20 times lower indicating a cuscutain-specific inhibitory function. The data support the sequence predictions concerning the biochemical function for both the enzyme and the inhibitor component.

\section{Biological function of cuscutain}

Since cuscutain-mRNA was abundant in haustoria, a function of the encoded proteinase for the infection process was assumed. If cuscutain activity is essential for a successful infection, inhibition of the enzyme could be one way of reducing the effectiveness or preventing Cuscuta infestation. To test this assumption, 60 tobacco plants were prepared for infection by curling $20 \mathrm{~cm}$ Cuscuta shoot segments around the host shoot. One half of the assay was sprayed with $100 \mu \mathrm{g} / \mathrm{ml}$ buffered inhibitor propeptide solution 2 times a day for one week. As a mock control the other 30 plants were treated with buffer solution only. The propeptide solution had no visual effect on host tobacco plants e.g. with

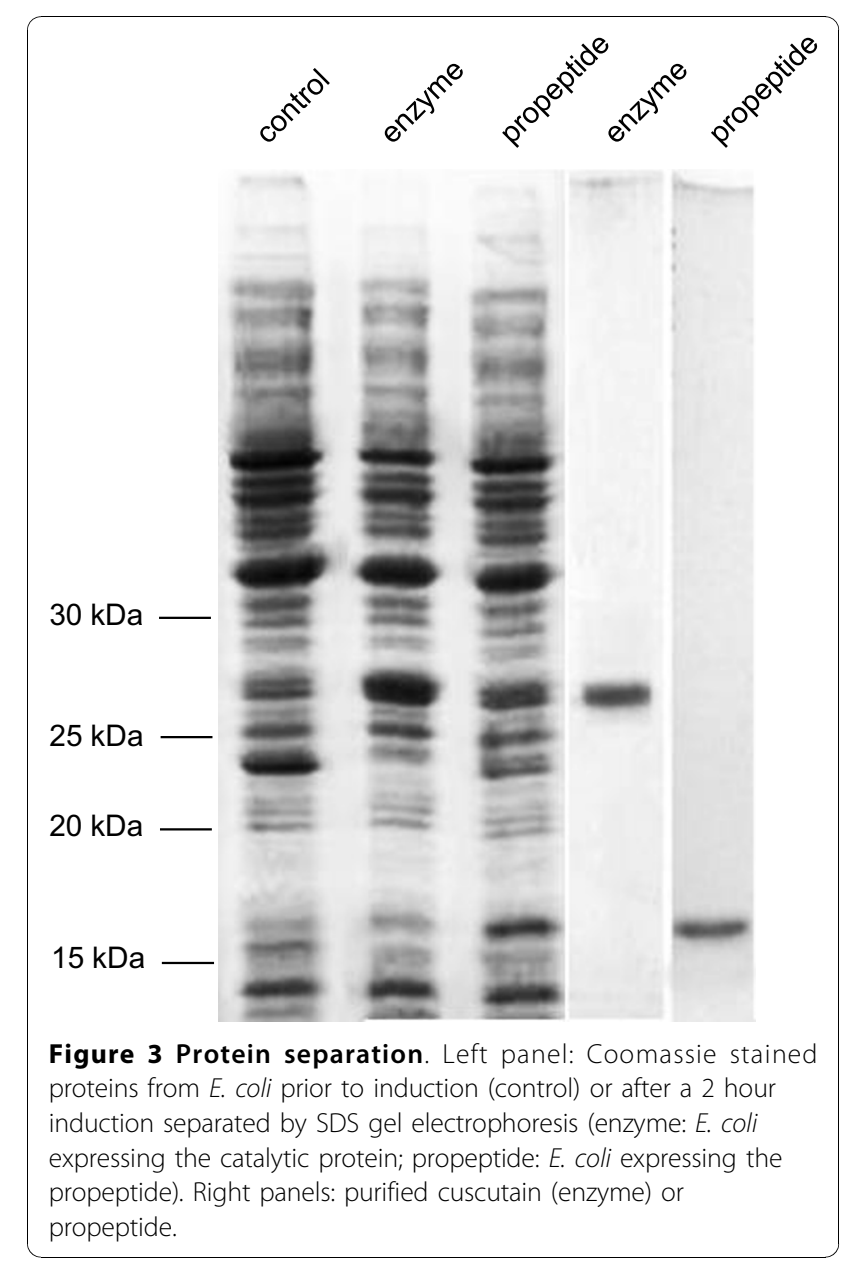




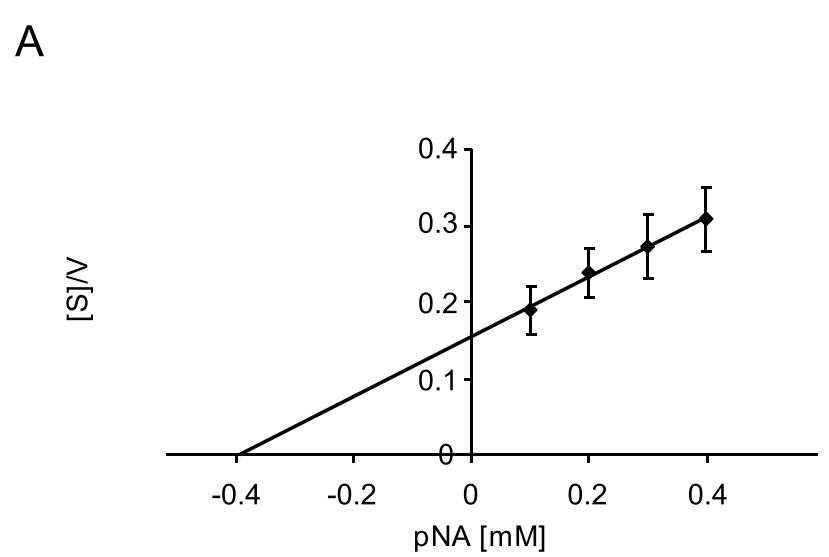

C

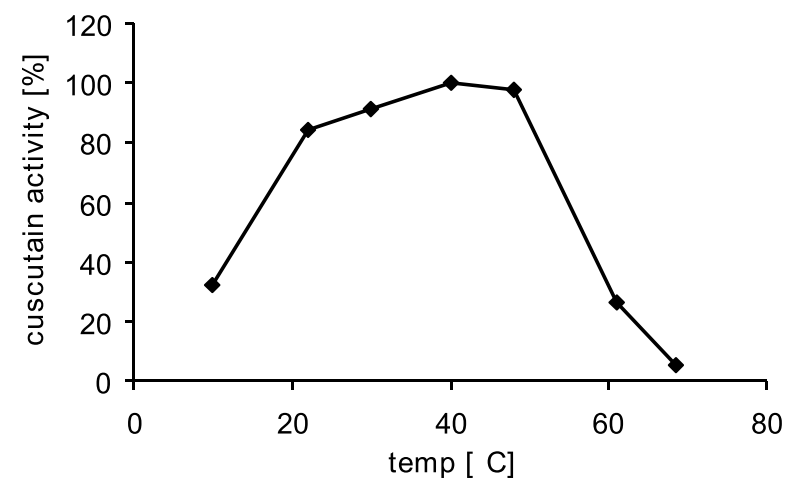

B

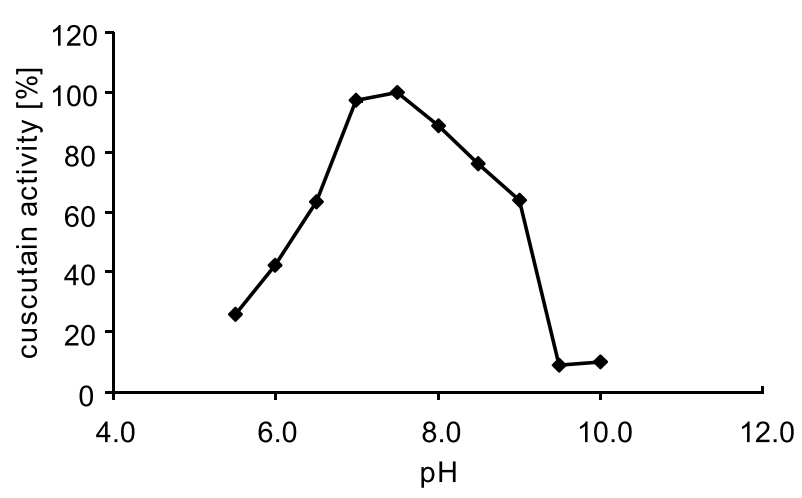

D

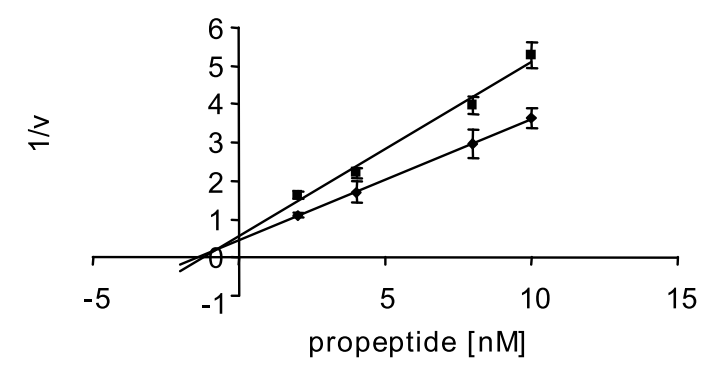

Figure 4 Biochemical characterization of cuscutain. A Hanes-Woolf plot of cuscutain activity for Km estimation. B relative cuscutain activity at different $\mathrm{pH}$ conditions. $\mathbf{C}$ relative cuscutain activity at different temperatures. D Dixon plot of cuscutain activity for estimation of inhibitor $\mathrm{K}_{\mathrm{i}}$.

regard to development. On a daily basis, the plants were monitored for prehaustoria, haustoria and attached haustoria. Parasites on inhibitor propeptide solution treated Cuscuta - host plants appeared to be thinner and less vital as compared to controls (Figure 5A, B). For a quantitative assessment, the number of prehaustoria and haustoria attached or not attached to the host, were counted and related to Cuscuta shoot length. Untreated plants developed on average $9( \pm 2.1)$ haustoria per $10 \mathrm{~cm}, 6( \pm 1)$ of these produced a successful connection via hyphae. Inhibitor treated plants had 5.6 $( \pm 1.6)$ haustoria per $10 \mathrm{~cm}$ with $1.5( \pm 0.5)$ successful penetrations and connections to the host vascular tissue.

Table 1 Biochemical characteristics of cysteine proteinases

\begin{tabular}{cccc}
\hline & Cuscutain & Cruzipain & Papain \\
\hline temperature Optimum $\left[{ }^{\circ} \mathrm{C}\right]$ & 40 & 37 & 25 \\
$\mathrm{pH}$ & 7,5 & 8,0 & 6,5 \\
$\mathrm{~K}_{\mathrm{m}}[\mathrm{mM}]$ & 0,4 & 0,003 & 0,4 \\
\hline
\end{tabular}

Biochemical characteristics of cuscutain, cruzipain [49] and papain [50,51].
On average treatment with the inhibitory propeptide solution reduced haustoria formation roughly by $40 \%$ and decreased successful parasite infestation from $65 \%$ down to $15 \%$. In most cases (29 out of 30), Cuscuta on treated plants dried out after about two weeks without further spraying (Figure 5c, d), which suggests that a minimum number of successful connections to host xylem and phloem per parasite shoot length is required for vitality and propagation of C. reflexa. It also indicates that an active cuscutain cysteine proteinase is a component of a successful Cuscuta infestation.

\section{Discussion}

A role of cuscutain during the infection process is suggested by the presented data. Accordingly, the sequence of related molecular events could be envisaged as follows: The cuscutain gene is activated concomitant to haustoria formation. The gene encodes a so called pre-pro-protein, with each of the protein subunits having a separate function. The prepeptide targets the cuscutain primary protein to the extracellular space. Here the unprocessed translation product is cleaved and deleted from the pre- 

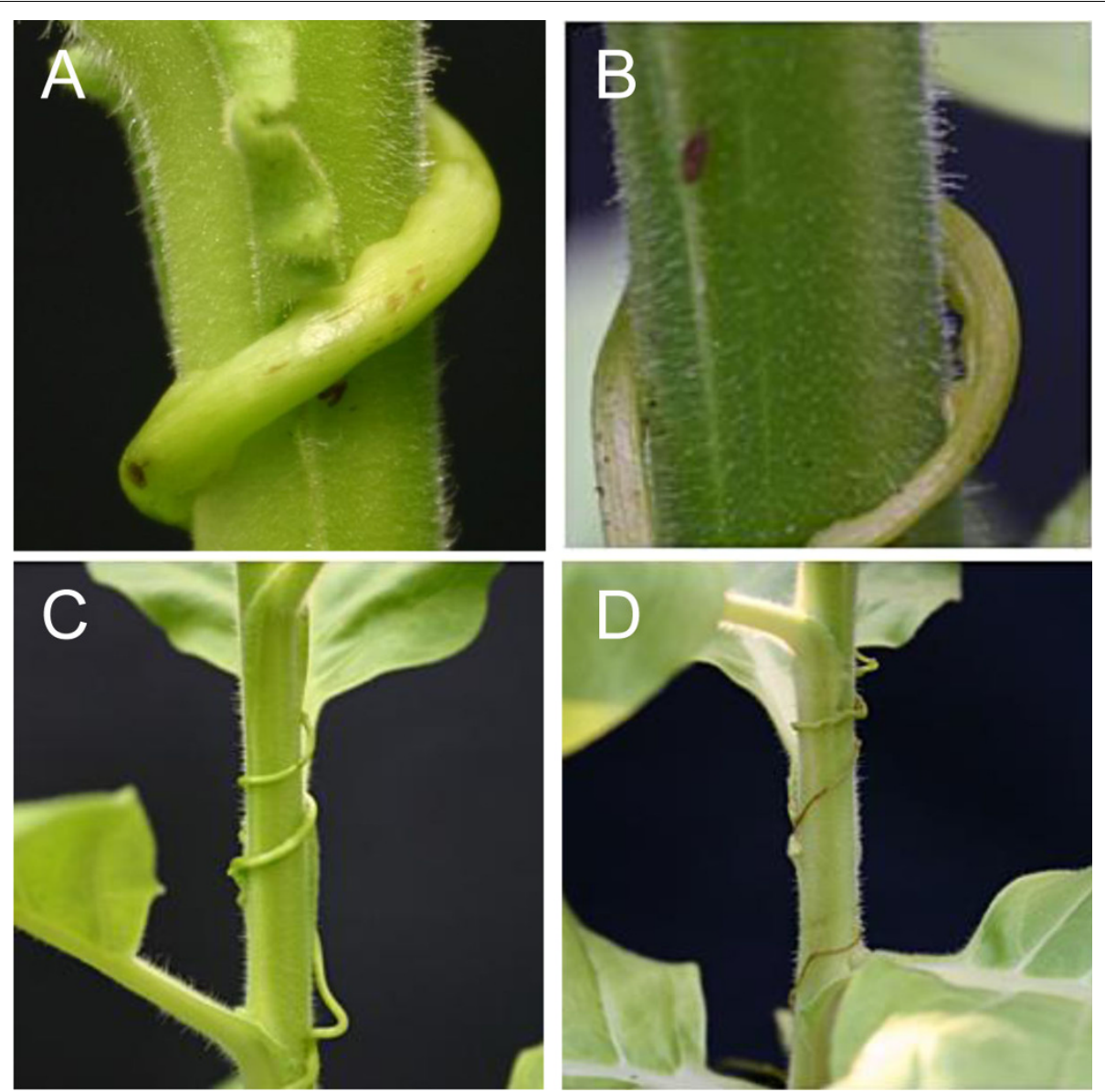

Figure 5 Cuscuta reflexa on tobacco. The parasite successfully attached to untreated plants $(\mathbf{A}, \mathbf{C})$, but not propeptide solution treated plants (B, D).

and propeptide. Deletion of the inhibitor-propeptide converts cuscutain from an inactive form to an active enzyme with a cysteine proteinase function. Outside the parasite, the enzyme fulfills a role in the successful infection process, possibly by weakening host structures through protein degradation. Therefore, addition of water inhibitor solution by spraying most likely restricts this enzymatic activity outside the haustorial cells. It is yet unclear how a host-specific cuscutain activity is achieved, since the enzyme is most likely localized in the vicinity of host and Cuscuta tissue. If a concentration gradient of effective inhibitor components from parasite to host is created from primary cuscutain processing, the enzyme would show higher activity close to the host. Protective structures, e.g. the high degree of pectins on haustoria surfaces, could be another factor favoring the degradation of host cells in comparison to parasite tissue.

It is assumed that degrading enzymes, which are either parasite- or host-encoded support the penetration of parasitic hyphae [24,25]. In this regard the role of cuscutain resembles that of Orobanche encoded enzymes which were located in the cytoplasm and cell walls of intrusive cells and in the adjacent host apoplast during haustorium penetration [26-29].

\section{Conclusions}

Papain-like cysteine proteases have been identified at the surface of various interaction surfaces between plants and pathogens like bacteria, fungi, oomycetes, nematodes insects or herbivores [30-40]. Some of these are a component of a defense mechanism while others are implicated in the parasitic pathogenic attack [41]. The identification of the cysteine proteinase cuscutain as a component that may be important for successful infestation of the parasitic plant C. reflexa could open the possibility for a new approach for development of parasitic plant blocking agents. During the parasite - host interactions both plant species act and react in order to invade, prevent, or tolerate invasion. Among others, these responses are visible as differential gene expression [42]. The identification of the corresponding proteins increases our knowledge about the molecular events of plant parasite infection. As 
demonstrated, the encoded proteins could also be significant for the host parasite interaction. There is a chance that a reduction of parasite-derived proteins weakens the parasite's infection efficiency and thereby strengthens host defense. However, prior to an application of a cuscutain propeptide solution in farming to protect crops some uncertainties must be ruled out. The inhibitor studies showed that its action spectrum is quite specific for cuscutain. It is unknown how similar cysteine proteases from other Cuscuta species or other parasitic plants are affected or if the inhibitor is effective on related proteases. It is possible that only one inhibitor is effective per species. On the other hand, the activity of cysteine proteinases could play a role in other parasitic plant interactions such as those with Orobanche or Striga. Although the latter parasitic weeds are root- and not shoot-parasites, the possibility of consistencies at the molecular level exists. Inhibition of cysteine proteases could thus be of wider importance for antagonizing parasitic plants from different genera.

\section{Methods}

\section{Plant material and growth conditions}

Tobacco plants were grown in standard potting soil under $16 \mathrm{~h} / 8 \mathrm{~h}$ day/night light conditions $(800 \mu \mathrm{mol}$ photons $\mathrm{m}^{2} \mathrm{~s}^{-1}$ ) at $25{ }^{\circ} \mathrm{C}$. Cuscuta reflexa was grown on Coleus blumei host plants under the same greenhouse conditions as the tobacco plants. Coleus blumei was chosen as host plant for Cuscuta cultivation because it tolerated this parasitic infection. C. reflexa was propagated vegetatively throughout. For infection of tobacco plants, $C$. reflexa shoot tips of about $20 \mathrm{~cm}$ length were wrapped around a wooden stick. After $24 \mathrm{~h}$, C. reflexa shoots were transferred to 4-5-week-old tobacco plants and curled around the stem; this time point was set as the starting point of the infection process.

\section{Northern blot analysis}

RNA isolation from Cuscuta shoots was performed using the RNAeasy plant mini kit (Qiagen) following the manufacturer's instructions. The gel was loaded with 5 $\mu g$ RNA per lane and blotted onto a nylon membrane (Applichem Inc., Darmstadt, Germany). The blot was hybridized with a cDNA probe comprising $270 \mathrm{bp}$ of the open reading frame encoding the Cuscutain-enzyme active site. It was synthesized by PCR (forward primer: 5'-GGCGCGCCCCATACATTTGCTCCAAGCGG-3'; reverse primer: 5'-ATTTAAATGTGCTAACAGCTGCCACAGTTG-3'). The PCR reaction was carried out using DIGlabelled dUTPs. Membrane blots were prehybridized for $2 \mathrm{~h}$ in DigeasyHyb (Roche Diagnostics $\mathrm{GmbH}$, Mannheim, Germany); subsequently, the denatured probe was added for overnight hybridization at 42 ${ }^{\circ} \mathrm{C}$. Washing and detection was performed following the manufacturer's protocol. Detection was carried out following the suppliers protocol (Pharmacia Biotech, Munich, Germany) using an alkaline phosphataseconjugated antibody and CDPstar as substrate for chemiluminescence reaction. The chemiluminescence was visualized and quantified using a chemiluminescence detector equipped with a digital camera and quantification software (BioRad).

\section{Comparative macroarray}

Tissue samples of Cuscuta reflexa including prehaustoria and haustoria were collected 3 days after the infection of 5 weeks old tobacco plants. Total RNA was isolated using RNAeasy plant mini kit (Qiagen, Germany) following the manufacturer's instructions. $2 \mu \mathrm{g}$ total RNA was employed for first strand cDNA synthesis (Ready-To-Go" You-Prime First-Strand Beads; GE Healthcare) using 3'CDS-primer and SMARTIIA-oligo-primer from SMART $^{\mathrm{m}}$ cDNA synthesis system (Clontech). cDNA was PCR amplified applying the above mentioned primers and the product was cloned via TA cloning (TOPO TA Cloning, Invitrogen). Colonies of transformed bacteria were selected on Ampicillin $(50 \mu \mathrm{g} / \mathrm{ml})$ containing agar plates using blue/white selection (LB-agar plates: $1 \%$ $\mathrm{NaCl}, 1 \%$ Trypton, $0.5 \%$ yeast extract, $1.5 \%$ agar, $60 \mu \mathrm{g} /$

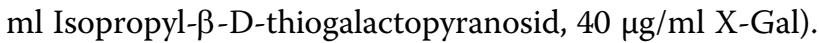
White colonies were transferred into a 96 well plate, each well filled with $200 \mu \mathrm{l} \mathrm{LB}(1 \% \mathrm{NaCl}, 1 \%$ Trypton, $0.5 \%$ yeast extract), grown overnight and stored after addition of one drop of glycerol $(90 \%)$ at $-80^{\circ} \mathrm{C}$. An aliquot of the E.coli stock $(10 \mu \mathrm{l})$ was subjected to PCR amplification of the plasmids cDNA insertion using vector specific primers and following standard procedures to a product end concentration of 70- $100 \mathrm{ng} / \mu \mathrm{l}$ in a 96 well plate. Using a

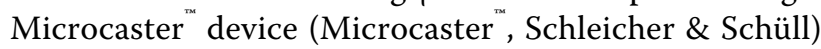
768 amplified cDNAs were stamped to a Castslide (Schleicher\& Schüll) having an area of about $2 \mathrm{~cm}^{2}$. After the punctual application of cDNAs the slides were treated with denaturing solution $(0.4 \mathrm{M} \mathrm{NaOH}, 3 \times \mathrm{SSC}$, $10 \mathrm{mM}$ EDTA) for 5 minutes and then with a neutralizing buffer (0.5M Tris-HCL pH 7.0, 1.5 M NaCl). For the differential hybridization a single stranded cDNA probe from total RNA of Cuscuta reflexa shoot material without prehaustoria and haustoria or with prehaustoria and haustoria was labelled using Label Star Array Kit (Quiagen) and ${ }^{33}$ P.dCTP. After incubation for $1 \mathrm{~h}$ at $42{ }^{\circ} \mathrm{C}$ with PreHyb/Wash Buffer (CAST"' MicroHybridization Kit, Schleicher \& Schüll) the slides were incubated in a volume of $1 \mathrm{ml}$ and 1 million cpm labelled cDNA over night at $42{ }^{\circ} \mathrm{C}$. The slides were washed 3 times for 30 minutes at room temperature with PreHyb/Wash Buffer and the hybridization signals detected and quantified with a Phoshorimager (BAS-1800 Scanner, BasReader, Fuji). 7000 cDNAs were screened and 16 corresponding 
genes that were identified to be clearly upregulated in the haustoria containing fraction were identified.

\section{Sequence comparison and predictions}

Sequence based comparisons with the Cuscutain cDNA were performed by web-based tools at NCBI (http:// www.ncbi.nlm.nih.gov). Cleavage site prediction of the deduced Cuscutain pre-pro-protein was determined by application of Protein Machine software available at Expasy (http://us.expasy.org/tools/).

\section{Expression and isolation of the propeptide and cuscutain}

The plasmid for the expression of the propeptide inhibitor fragment (amino acid residues 32-134) and the cuscutain enzymatic region (amino acid residues 135-367) were constructed using the GATEWAY ${ }^{\mathrm{m}}$-system (Invitrogen) according to the manufacturer's protocol [43]. Entry vector pDonr201 and destination vector pETDest 42 (Invitrogen) were used for cloning the respective $\mathrm{Cuscu}$ tain cDNA or cDNA fragment in frame with a $6 \mathrm{x}$ His tag at the protein's C-terminus. The propeptide containing polypeptide and that with cuscutain were expressed in E. coli (BL21Lys). $100 \mathrm{ml}$ of E. coli suspension was grown in an appropriate Erlenmeyer flask in LB [44] at $37^{\circ} \mathrm{C}$. At an O.D. of 0.8 , the $1 \mathrm{mM}$ IPTG was added for 4 hours and the suspension centrifuged for $10 \mathrm{~min}$ at $13.000 \mathrm{rpm}$. The supernatant was discarded and the cells resuspended in $4 \mathrm{ml}$ of resuspension buffer (50 M Na-phosphate, pH 7.5, $4 \mathrm{M}$ urea, $300 \mathrm{mM} \mathrm{NaCl}$ ). The HIS-tagged propeptide was allowed to bind to pre-equilibrated BD TALON ${ }^{\text {"m }}$ metal affinity resin (Clontech) overnight at $4{ }^{\circ} \mathrm{C}$. Subsequently, the resin was washed 3 times with resuspension buffer. Bound protein was eluted using $1 \mathrm{ml}$ of elution buffer (50 M Na-phosphate, $\mathrm{pH} 7.5,4 \mathrm{M}$ urea, $300 \mathrm{mM} \mathrm{NaCl}$ and $150 \mathrm{mM}$ Imidazole). Prior to further analysis, the obtained solution was dialysed against $50 \mathrm{mM}$ Na-phosphate, pH 7.5. E. coli expressing cuscutain were resuspended in $1.5 \mathrm{ml}$ electrophoresis buffer (0.25 M Tris-HCl, pH6.8, Glycerol 50\%, SDS 0.2 g), subjected to sonification and separated by SDS-gel electrophoresis using standard methods [45]. By comparison to a parallel Coomassie stained gel, the lanes containing cuscutain were identified and cut out. The HIS tagged cuscutain enzymatic region was eluted using the Elutrap system (Schleicher \& Schüll) following to the manufactures' protocol. Elution was performed overnight at $80 \mathrm{~V}$. SDS was removed from the sample using the method of Henderson et al. [46]. To ensure cuscutain enzymatic a buffer containing $40 \mathrm{mM}$ Tris/borate, $\mathrm{pH}$ $8.5,50 \%$ glycerol, $3 \mathrm{mM}$ glutathione was added drop wise to a sample dilution of $200: 1$ and incubated overnight at $4{ }^{\circ} \mathrm{C}$ according a protocol provided by Tobbell et al [47]. For protein concentration, the solution was electro eluted again at $200 \mathrm{~V}$. Purified proteins were stored at $-20^{\circ} \mathrm{C}$.

\section{Kinetic Measurements}

Cuscutain activity was determined using the colorimetric papain substrate Cbz-Phe-Arg-pNA. In brief $12.08 \mu \mathrm{M}$ cuscutain and $0.4 \mathrm{mM}$ dipeptide in $500 \mu \mathrm{l} 0.1$ M Na-citrate, pH 7.5, containing 20\% ethanol, were incubated at $37^{\circ} \mathrm{C}$ for $10 \mathrm{~min}$. After addition of $500 \mu \mathrm{l} 5$ $\mathrm{mM}$ PMSF in DMSO, absorbance of para-nitroaniline was measured at a wavelength of $405 \mathrm{~nm}$. Cbz-Phe-ArgpNA concentrations of $0.2 \mathrm{mM}$ and $0.4 \mathrm{mM}$ were used for $1 / \mathrm{v}$ versus [I] plots [48]. All measurements for cuscutain were performed at $30{ }^{\circ} \mathrm{C}$, and assay conditions were $50 \mathrm{mM}$ Tris-buffer, $\mathrm{pH} 7.5$ containing $300 \mathrm{mM}$ $\mathrm{NaCl}$. The presented data rely on three independent experiments throughout.

\section{Acknowledgements}

The project was funded by DFG (Deutsche Forschungsgemeinschaft). We thank David T. Hanson (University of New Mexico) for critical reviewing the manuscript.

\section{Author details}

${ }^{1}$ Pathology of Forest Trees, TU Munich, Am Hochanger 13, 85354 Freising, Germany. ${ }^{2}$ ZMBP, Forschungsgruppe Pflanzenbiochemie, Eberhard-KarlsUniversität Tübingen, Auf der Morgenstelle 5, D-72076 Tübingen, Germany. ${ }^{3}$ University of Applied Sciences, Chemistry and Biotechnology, Schnittspahnstr. 12, 64287 Darmstadt, Germany. ${ }^{4}$ Darmstadt University of Technology, Applied Plant Science, Schnittspahnstr. 10, 64287 Darmstadt, Germany.

\section{Author's contributions}

MB: Isolated and characterized cuscutain. Performed biological significance tests. MA: Constructed cDNA-library and screening. LF: Significantly contributed to enzymatic characterization of cuscutain. RK: Contributed to conception and design, analysis and interpretation of data. Was involved in drafting the manuscript and revising it critically for important intellectual content. All authors read and approved the final manuscript.

Received: 19 May 2010 Accepted: 22 October 2010

Published: 22 October 2010

\section{References}

1. Dawson JH, Musselman $\sqcup$, Wolswinkel PD I: Biology and Control of Cuscuta. Weed Science 1994, 6:265-317.

2. Nadler-Hassar T, Shaner DL, Nissen S, Westra P, Rubin B: Are herbicideresistant crops the answer to controlling Cuscuta? Pest Manag Sci 2009, 65:811-816.

3. Nadler-Hassar T, Rubin B: Natural tolerance of Cuscuta campestris to herbicides inhibiting amino acid biosynthesis. Weed Research 2003, 43:341-347.

4. Yoder J, Gunathilake P, Wu B, Tomilova N, Tomilov AA: Engineering host resistance against parasitic weeds with RNA interference. Pest Management Science 2009, 65:460-466

5. Li DM, Staehelin C, Zhang YS, Peng SL: Identification of genes differentially expressed in Mikania micrantha during Cuscuta campestris infection by suppression subtractive hybridization. Journal of Plant Physiology 2009, 166:1423-1435.

6. Li DM, Staehelin C, Zhang YS, Peng SL: Identification of genes differentially expressed in Mikania micrantha during Cuscuta campestris infection by suppression subtractive hybridization. Journal of Plant Physiology 2009, 166:1423-1435.

7. Die JV, Verdejo CIG, Dita MA, Nadal S, Roman B: Gene expression analysis of molecular mechanisms of defense induced in Medicago truncatula parasitized by Orobanche crenata. Plant Physiology and Biochemistry 2009, 47:635-641. 
8. Li JX, Lis KE, Timko MP: Molecular genetics of race-specific resistance of cowpea to Striga gesnerioides (Wilid.). Pest Management Science 2009, 65:520-527.

9. Hamamouch N, Westwood JH, Banner I, Cramer CL, Gepstein S, Aly R: A peptide from insects protects transgenic tobacco from a parasitic weed. Transgenic Res 2005, 14:227-236.

10. Castillejo MA, Maldonado AM, Dumas-Gaudot E, Fernandez-Aparicio M, Susin R, Diego R, et al: Differential expression proteomics to investigate responses and resistance to Orobanche crenata in Medicago truncatula. Bmc Genomics 2009, 10.

11. Albert M, Werner M, Proksch P, Fry SC, Kaldenhoff R: The cell wallmodifying xyloglucan endotransglycosylase/hydrolase LeXTH1 is expressed during the defence reaction of tomato against the plant parasite Cuscuta reflexa. Plant Biol 2004, 6:402-407.

12. Albert M, Belastegui-Macadam X, Kaldenhoff R: An attack of the plant parasite Cuscuta reflexa induces the expression of attAGP, an attachment protein of the host tomato. Plant J 2006, 48:584-586.

13. van der Kooij TA, Krause K, Dorr I, Krupinska K: Molecular, functional and ultrastructural characterisation of plastids from six species of the parasitic flowering plant genus Cuscuta. Planta 2000, 210:701-707.

14. Hibberd JM, Bungard RA, Press MC, Jeschke WD, Scholes JD, Quick WP: Localization of photosynthetic metabolism in the parasitic angiosperm Cuscuta reflexa. Planta 1998, 205:506-513.

15. Vaughn KC: Attachment of the parasitic weed dodder to the host. Protoplasma 2002, 219:227-237.

16. Albert $M$, van der Krol $A$, Kaldenhoff $R$ : Cuscuta reflexa invasion induces $\mathrm{Ca}^{2+}$ release in its host. Plant Biol 2010, 12:554-557.

17. Vaughn KC: Dodder hyphae invade the host: a structural and immunocytochemical characterization. Protoplasma 2003, 220:189-200

18. Birschwilks M, Haupt S, Hofius D, Neumann S: Transfer of phloem-mobile substances from the host plants to the holoparasite Cuscuta sp. Journal of Experimental Botany 2006, 57:911-921.

19. Haupt S, Oparka KJ, Sauer N, Neumann S: Macromolecular trafficking between Nicotiana tabacum and the holoparasite Cuscuta reflexa. Journal of Experimental Botany 2001, 52:173-177.

20. Westwood JH, Roney JK, Khatibi PA, Stromberg VK: RNA translocation between parasitic plants and their hosts. Pest Management Science 2009, 65:533-539.

21. Karrer KM, Peiffer SL, DiTomas ME: Two distinct gene subfamilies within the family of cysteine protease genes. Proc Natl Acad Sci USA 1993, 90:3063-3067.

22. Coulombe R, Grochulski P, Sivaraman J, Menard R, Mort JS, Cygler M: Structure of human procathepsin $L$ reveals the molecular basis of inhibition by the prosegment. EMBO J 1996, 15:5492-5503.

23. Smith SM, Gottesman MM: Activity and deletion analysis of recombinant human cathepsin L expressed in Escherichia coli. J Biol Chem 1989, 264:20487-20495.

24. Yao DR, Zheng XM, uang JZ YH: Changes of acid phosphatase and cytokinins during haustorial development of the parasitic plant Cassytha filiformis L. Acta Botanica Sinica 1994, 36:170-174.

25. Yoder Jl: Parasitic plant responses to host plant signals: a model for subterranean plant-plant interactions. Curr Opin Plant Biol 1999, 2:65-70.

26. Ben-Hod G, Losner D, Joel DM, Mayer AM: Pectin methylesterase in calli and germinating seeds of Orobanche aegyptiaca. Phytochem 1993, 32:1399-1402.

27. Nun NB, Ben-Hod G, Lavi E, Mayer AM: Purification of pectin methylesterase from Orobanche aegyptiaca. Phytochem 1996, 41:403-406.

28. Ben-Hod G, Nun NB, Tzaban S, Mayer AM: Inhibitors of polygalacturonase in calli of Orobanche aegyptiaca. Phytochem 1997, 45:1115-1121.

29. LOSNER-GOSHEN DALI, Portnoy VH, Mayer AM, Joel DM: Pectolytic Activity by the Haustorium of the Parasitic PlantOrobancheL. (Orobanchaceae) in Host Roots. Annals of Botany 1998, 81:319-326.

30. Dvorak J, Mashiyama ST, Sajid M, Braschi S, Delcroix M, Schneider EL, et al: SmCL3, a Gastrodermal Cysteine Protease of the Human Blood Fluke Schistosoma mansoni. Plos Neglected Tropical Diseases 2009, 3.

31. Rebello KM, Cortes LMC, Pereira BAS, Pascarelli BMO, Corte-Real S, Finkelstein $L C$, et al: Cysteine proteinases from promastigotes of Leishmania (Viannia) braziliensis. Parasitology Research 2009, 106:95-104.

32. Duschak VG, Couto AS: Cruzipain, the Major Cysteine Protease of Trypanosoma cruzi: A Sulfated Glycoprotein Antigen as Relevant
Candidate for Vaccine Development and Drug Target. A Review. Current Medicinal Chemistry 2009, 16:3174-3202.

33. Freitas MAR, Fernandes HC, Calixto VC, Martins AS, Silva EF, Pesquero JL, et al: Entamoeba histolytica: Cysteine proteinase activity and virulence. Focus on cysteine proteinase 5 expression levels. Experimental Parasitology 2009, 122:306-309.

34. Serbielle C, Moreau S, Veillard F, Voldoire E, Bezier A, Mannucci MA, et al: Identification of parasite-responsive cysteine proteases in Manduca sexta. Biological Chemistry 2009, 390:493-502.

35. De Jesus LB, Cuervo P, Britto C, Saboia-Vahia L, Silva FCE, Borges-Veloso A, et al: Cysteine Peptidase Expression in Trichomonas vaginalis Isolates Displaying High- and Low-Virulence Phenotypes. Journal of Proteome Research 2009, 8:1555-1564.

36. Marin-Villa M, Vargas-Inc, Chaves SP, Tempone AJ, Dutra JMF, Soares MJ, et al: The C-terminal extension of Leishmania pifanoi amastigote-specific cysteine proteinase Lpcys2: A putative function in macrophage infection. Molecular and Biochemical Parasitology 2008, 162:52-59.

37. Myers J, Ittiprasert W, Raghavan N, Miller A, Knight M: Differences in cysteine protease activity in Schistosoma mansoni-resistant and -susceptible Biomphalaria glabrata and characterization of the hepatopancreas cathepsin B full-length cDNA. Journal of Parasitology 2008, 94:659-668.

38. Kaewpitoon N, Laha T, Kaewkes S, Yongvanit P, Brindley PJ, Loukas A, et al: Characterization of cysteine proteases from the carcinogenic liver fluke, Opisthorchis viverrini. Parasitology Research 2008, 102:757-764

39. Konarev $\mathrm{AV}$ : Interaction of insect digestive enzymes with plant protein inhibitors and host-parasite coevolution. Euphytica 1996, 92:89-94.

40. Shen $H$, Ye W, Hong L, Huang H, Wang Z, Deng X, et al: Progress in parasitic plant biology: Host selection and nutrient transfer. Plant Biol 2006, 8:175-185.

41. Shindo T, Van der Hoorn RA: Papain-like cysteine proteases: key players at molecular battlefields employed by both plants and their invaders. Mol Plant Pathol 2008, 9:119-125.

42. Irving L, Cameron DD: You are What You Eat: Interactions Between Root Parasitic Plants and Their Hosts. Advances in Botanical Research, Vol 50 2009, 50:87-138.

43. Landy A: Dynamic, structural, and regulatory aspects of lambda sitespecific recombination. Annu Rev Biochem 1989, 58:913-949.

44. Bertani G: Studies on lysogenesis. I. The mode of phage liberation by lysogenic Escherichia coli. J Bacteriol 1951, 62:293-300.

45. Laemmli UK: Cleavage of structural proteins during the assembly of the head of bacteriophage T4. Nature 1970, 227:680-685.

46. Henderson LE, Oroszlan S, Konigsberg W: Micromethod for Complete Removal of Dodecyl-Sulfate from Proteins by lon-Pair Extraction. Analytical Biochemistry 1979, 93:153-157.

47. Tobbell DA, Middleton BJ, Raines S, Needham MR, Taylor IW, Beveridge JY, et al: Identification of in vitro folding conditions for procathepsin $\mathrm{S}$ and cathepsin S using fractional factorial screens. Protein Expr Purif 2002, 24:242-254.

48. Dixon M: The Determination of Enzyme Inhibitor Constants. Biochem $J$ 1953, 55:170-171.

49. Salvati L, Mattu M, Polticelli F, Tiberi F, Gradoni L, Venturini G, et al: Modulation of the catalytic activity of cruzipain, the major cysteine proteinase from Trypanosoma cruzi, by temperature and $\mathrm{pH}$. Eur J Biochem 2001, 268:3253-3258

50. Sajid M, McKerrow JH: Cysteine proteases of parasitic organisms. Mol Biochem Parasitol 2002, 120:1-21.

51. Menard R, Khouri HE, Plouffe C, Dupras R, Ripoll D, Vernet T, et al: A protein engineering study of the role of aspartate 158 in the catalytic mechanism of papain. Biochemistry 1990, 29:6706-6713.

doi:10.1186/1471-2229-10-227

Cite this article as: Bleischwitz et al: Significance of Cuscutain, a cysteine protease from Cuscuta reflexa, in host-parasite interactions. BMC Plant Biology 2010 10:227. 